literatury, 2007. $-256 \mathrm{~s}$.

5. Kobyrynka H. Pryiomy y metody analizu paroksytonezy na tli vilnoho, rukhomoho naholosu v ukrainskykh hovirkakh / H. Kobyrynka // Ukrainska mova. - 2016. - № 2-S. $14-23$.

6. Huivaniuk N.V. Ukrainska mova. Skhemy, tablytsi, testy : Navchalnyi posibnyk / N.V. Huivaniuk, O.V. Karashchuk, O.V. Kulbabska. - Lviv: Svit, 2005. - 304 s.

7. Skliarenko V.H. Narysy z istorychnoi aktsentolohii ukrainskoi movy / V.H. Skliarenko. - Kyiv: Naukova dumka, 1983. $-240 \mathrm{~s}$.

8. Kurylovych E. Struktura morfem / E.Kurylovych. - Moskva: Yzd-vo ynostrannoi lyteraturb, 1962. - 452 s.

9. Hlazova O. P. Ridna mova: pidruch. dlia 5 kl. zahalnoosvit. navch. zakl. / O.P. Hlazova, Yu.B. Kuznetsov; nauk. red. I. Vykhovanets. - Kyiv: Pedahohichna presa, 2005. - $288 \mathrm{~s}$.

10. Mytropolyt Ilarion Ukrainskyi literaturnyi naholos. Movoznavcha monohrafiia / Ilarion Mytropolyt. Vinnipeh, 1952. $-306 \mathrm{~s}$.

Отримано редакцією 15.10 .2018 р.

UDK 372.888.111.1

\author{
DOI: 10.31376/2410-0897-2018-3-38-91-96 \\ Natalia Soroka, \\ $\mathrm{PhD}$ in Psychology, \\ associate professor foreign languages № 2 chair \\ Yaroslav Mudryi National Law University, \\ e-mail: alfa155_sv@ukr.net
}

\author{
Margaryta Zaitseva, \\ $\mathrm{PhD}$ in Philology, \\ associate professor foreign languages № 2 chair \\ Yaroslav Mudryi National Law University, \\ e-mail: margozay@i.ua
}

\title{
PSYCHOLOGICAL AND PEDAGOGICAL RECOMMENDATIONS FOR STUDENTS CONCERNING PROFESSIONALLY ORIENTED PRESENTATIONS IN ENGLISH
}

The article deals with the problem of delivering presentations by law students. It is explained that the commonplace objective of the contemporary foreign language teaching has always been and still is the formation of communicative competence which includes public speaking skills which is best achieved through presentations. The article specifies an algorithm that should be taken into account when developing a presentation: the main idea of the presentation, the length of the presentation, the presentation structure, the interactivity of the presentation, the presentation visibility. In addition, the authors have recommended some psychological and methodological tips to prepare and make students' presentations perfect.

Key words: communicative competence, delivering presentation, professional communication, communicative competence, public speaking skills, delivering presentation, professional communication, interactive presentation, presentation visibility.

Statement of the problem. The process of mastering English-speaking legal discourse is inextricably linked with the formation of a professionally oriented language personality in the legal field, capable of participating in professional intercultural communication.

The expansion of international relations and integration processes require future specialists to have a better command of a foreign language in order to overcome language barriers in the context of international cooperation. Professionally-oriented foreign language is one of compulsory disciplines in all non-linguistic higher educational institutions since it is the basis for the development of foreign language competence of students as one of the components of professional competence. This factor provides the opportunity to use the linguistic system for communication in general as well as in the particularly narrow professional situations. Today, the requirements of a foreign language acquisition for lawyers are substantially changing. Practical skills and abilities that provide a high level of professional linguistic and cultural competence within oral and written business communication come to the first place. Professional lawyers working in the area of international law are confronted with the need to participate in various types of direct and indirect intercultural communication in the process of fulfilling their duties.

Analysis of recent research and publications. The awareness of the need to master a foreign language as an instrument of intercultural communication in professional legal and other relevant areas is a topical issue for future lawyers. The theoretical foundations for the reform of higher education have been created in Ukraine by 
certain fundamental documents [1-3]. Such modern scholars such as V. A. Artemov, T. Mishenina, V. V. Krayevsky, M. S. Golovan, Yu. A. Komarova, B. A. Lapidus, S. V. Smolina, V. A. Buhbinder and many others have devoted their works to the methodological aspect of teaching foreign languages. I. Y. Troitskaya, G. F. Kirova, O. A. Artemyeva, L. G. Kuzmin, O. B. Tarnopolsky and others [5], the representatives of pedagogical and psychological schools analyzed in their works the issue of foreign language teaching for future lawyers. However, despite a wide range of studies, the relevance of the problem of training communicative professional competence remains the question of the hour.

Formulating the purpose of the article. The purpose of the article is to determine the psychological and pedagogical principles for the most effective teaching of students in the field of mastering the skills of foreignlanguage professional material presentation within the content of foreign language training of bachelors majoring in «International Law» in the framework of the first educational qualification level (bachelor).

Methods. The following theoretical methods of pedagogical research have been used in the article: study of literature, theoretical analysis, methods of logical generalization. Together with the theoretical methods there are also practical methods that have been applied. They include observation, conversation, and questioning.

Presentation of the main material. The commonplace objective of the contemporary foreign language teaching has always been and still is the formation of communicative competence which includes public speaking skills. According to the European Recommendations on language education [4], the following competencies should be formed as a result of mastering the academic discipline: knowledge and ability to use foreign language vocabulary consisting of lexical and grammatical components, the ability to understand and control the organization of the content at the lexical, grammatical level and in terms of pragmatic semantics, the knowledge and skills necessary to implement the social aspect of foreign language use, knowledge of linguistics markers of social relations, knowledge of the principles of organizing and constructing speech/communication and programming speech, the ability to use in the communication foreign oral and written texts with special functional purposes through the provision and request of factual information, expression and identification of the attitude to facts, knowledge, modality, expression of will, emotions and morals, motivation, socialization, structuring of speech and restoration of communication, and others. All skills and knowledge, mentioned above, form the basis for such kind of communicative activity as presentation or public speaking. Having learned the basic foreign language, based on grammar rules and vocabulary, public speaking stays the number one phobia for many learners. Students are more afraid of speaking in public than doing any other activity. At some point our learners will have to give a presentation. For many of our students this is a different type of skill they have to learn and their struggle with the language makes it more frightening for them. For teachers this can be difficult to teach because we teach rehearsed language as well as presentation skills and presentation design skills. However, teaching our learners how to present helps them with their English related to their working environment, and provides them with a confidence and motivation to continue their English.

In general, the language personality of a lawyer is characterized by the following qualities:

1. possession of a professional subject picture of the world;

2. possession of a professional language picture of the world;

3. the ability to interpret and argue legal facts and events;

4. ability to carry out oral and written professional communication [5, p. 75].

According to $\mathrm{Yu}$. Karaulov there are three levels of language personality:

- zero level (verbal-semantic);

- the first level (linguo-cognitive);

- second level (motivational) [6, p. 238].

The verbal and semantic level conforms to proficiency in spoken language. This level includes separate words, the most standard phrases, simple sentences.

The linguo-cognitive level reflects the model of the world in the language. This level includes concepts, notions, ideas. They are expressed by the same words of zero level, but now they have a descriptor status. The relations between these means are arranged in a strict, hierarchical system that to some extent reflects the picture of the world. As stereotypes of the first level Yu. Karaulov terms aphorisms, catch phrases, proverbs and sayings.

The motivational level includes the identification and characterization of motives and goals, which lead to the development of the language personality and controlling its textual production and, ultimately, defining the hierarchy of meanings and values in its language. As means of the motivational level, not words and elements of the thesaurus are distinguished, but communicative and activity needs. Yu. Karaulov believes that since communication does not exist in and of itself but is related to the productive activity of people, it would be correct to speak not about purely communicative needs, but about communicative and activity needs, resulting from the entire paradigm of the person's social activity, covering also its interests, motives, goals and values [6, p. 66].

The ultimate goal of the academic discipline of mastering a foreign language is to form an intercultural communicative professionally oriented competence, which is represented by a list of interrelated and interdependent 
competences represented in the skill format. The objectives of the course of the academic discipline involve the consistent mastery of the students by a set of competences, which in the real learning process are, in the main, integrated into the solution of specific professional and communicative tasks aimed at achieving an appropriate communicative effect.

In the program for the bachelors of the International Law Faculty of the full-time form of education, there are two stages. The first stage provides, first of all, learning a common language. At the second stage, the priority is given to the professional language, communicative competence is achieved, which is necessary for professional communication and cooperation on a wide range of issues, as well as for foreign-language activity in studying and creative comprehension of foreign experience [5, p. 9].

During the first stage, a communicative competence is created, sufficient for further training in the chosen specialty, for carrying out every day and business contacts at the elementary level, for acquaintance with foreign experience in the legal area. Basically, at this stage of training, the linguo-cognitive level of the secondary linguistic personality of the future lawyer is formed. However, we believe that at this level of education, it is possible to begin the formation of a motivational level of students based on the development of the ability to present presentations on a professional topic, which will make it easier for students to turn to the second stage of training. The task at the first stage of training is to teach students to make presentations in a foreign language, simulating a speech in front of a familiar audience.

Presentation - a kind of public monologic speech, a message in a specific social and communicative context (discourse), which has a clearly marked goal. The main purpose of the presentation is to convey to the audience the full information about the presentation in a convenient form. When preparing the presentation, it is necessary to define goals, analyze the audience, develop a plan for presenting some points of view, prepare demonstration materials, predict the questions that can come from the audience, and prepare for answers to them.

Second-year students of the International Law Faculty deal with the textbook «Introduction to International Legal English» by AmyKrois-Linder and Matt Firth [7]. We consider it expedient to form the students' ability to make presentations on the basis of supplementing and expanding the legal topics presented in the textbook. The theme for the presentation can be information about various legal documents, international organizations, known cases, etc., to which the authors of the textbook refer. For example, in Lesson 10, the topic of Comparative Law is discussed, and the first text refers to such organizations as The Hague Conference on Private International (HCC), The International Institute for the Unification of Private Law (UNIDROIT), and The Uniform Law on International Sales of Goods, 1964.

The information presented in any small text is very condensed and does not give a full understanding of the goals, the history of the creation, the functions and the current relevance of these organizations and the abovementioned document. It seems advisable at the stage of passing this topic to invite students to prepare presentations of the above-mentioned organizations. At the same time, it should be mentioned that this material, in accordance with the principle of intersubjective coordination, which stipulates that the study of professionally significant topics in the native language should outstrip their study in a foreign language, has already been studied in lectures and seminars in the native language. Before the students themselves start working on their presentations, it is necessary to analyze with them a number of presentations on the legal subject, which, for example, are available on the website www.lawsessions.com. The analysis of these presentations in the lesson will help students to better understand the task facing them, to understand the structure of the presentation, to introduce peculiarities of non-verbal behavior of the speaker. When preparing a presentation, the teacher needs to help student identify a series of issues:

- the purpose of presentation;

- the main idea of presentation;

- duration of presentation;

- structure of presentation;

- interactivity of the presentation;

- visibility of presentation.

Here are some psychological and methodological tips to prepare and make your students' presentations perfect:

- Timing. It is quite important for a student to determine how long his talk should be. As he decides what to present, he should keep in mind that a ten-minute talk is very different from a 45-minute lecture. If the speaker only has ten minutes, he'll need to focus on the most important points. With more time, he'll still need to focus on those points, but there will be a good chance to present additional supporting detail. Instruct student to time himself giving his talk, and make cuts if he needs to. It is fine to end a bit early. Going overtime shows your lack of preparation.

- Audience. Remind students to be aware of what sort of audience will listen to his/her talk. Specialists in legal field will bring a different sort of understanding to the presentation from a general audience; the speaker may be able to use certain professional terms without defining them, but always beware of jargon and acronyms. With a general audience, there is a need for a student to ask himself what educated people not in his field will know, define 
any terms that may be unfamiliar to them, and make an effort to explain the significance of the research in terms the listeners are likely to understand.

- Content. Students often think they need to explain every single thing they know or be perceived as knowing too little. This is not true. Giving a talk is a great opportunity to think about the big picture rather than focusing on details. This can be hard if the student is immersed in the specifics of his project. Recommend him to step back for a moment to before he became the expert on his/her particular topic. What picked his/her interest? Why did he/she start asking the questions he/she asked? Now step into the future. When he/she looks back on this research, what will he/she remember as the most interesting or compelling thing he/she learned? Now he/she is ready to ask him/herself: What are the points I want to convey? What do I want the audience to learn? When audience members remember my talk the following day, what main point do I want them to remember?

- Organization. Students' presentation must have a beginning, middle, and end. They need to (1) introduce themselves; (2) present their research question and why it matters; (3) describe how they conducted their research, (4) explain what they found out and what it means; and (5) conclude with a summary of their main points. Depending on the topic, the student may need to provide background information so that the audience understands the significance of his inquiry. Instruct him to be judicious in the amount of information he gives, and do not let this discussion get him/her off track. Once he/she has provided sufficient background, bring the focus back to his/her research by reminding the audience of his/her research question. Recommend your students not even think of opening PowerPoint until they have organized their ideas and decided on their main points.

- PowerPoint. It's important to explain to students that to treat PowerPoint as a useful tool. They can use it to incorporate images into their presentation, toemphasize important points, and to guide the audience in following their argument. But they should not use it for anything else. This means: - don't present too much information on the slides. The audience cannot read a long section of text and simultaneously listen to you speak about it. If you really must provide a long quotation, then highlight the words and phrases you want to emphasize, and read the quote out loud, slowly, so the audience can absorb it. Then discuss it.

- explain to the audience what each term or notionmeans. Use terminology to convey information clearly, not simply to show the work is done.

- avoid spending extra time on making a fancy PowerPoint presentation with moving images and graphics unless they are vital for communicating speaker's ideas.

- be prepared to give the talk even if technology fails. If your charts don't look quite right on the screen, or you forget your flash drive, or there's a power outage, or half the audience can't see the screen, you should still be able to make an effective presentation. (Bring a printout to speak from, just in case any of these disasters befalls you).

- Tone. It is best to approach student's prepared talk as a somewhat formal occasion. The speaker should treat your audience - and his own topic - with respect. Even if he knows everyone in the room, introduce himself. Remind students never address audience members as «you guys», dress neatly. But most of allpersuade your students to share their enthusiasm for the subject.

- Practice. Teach students to practice speaking slowly and distinctly. If they want to emphasize an important point, they should repeat it.

Conclusions. The ability to give a presentation in a foreign language is an important component in the formation of the motivational level of the language personality of future lawyers. It will help the students to take part in professionally significant situations of communication: business negotiations, meetings, conferences, court hearings, etc. Professionally-oriented foreign language is one of compulsory disciplines in all non-linguistic higher educational institutions since it is the basis for the development of foreign language competence of students as one of the components of professional competence. The research is promising as it is necessary to analyze such issues that are closely connected with the topic as: emphatic structures in presentation, linking words and fillers in texts of presentations.

\section{References}

1. Zakon Ukrayinypro Osvitu (Vidomosti Verxovnoyi Rady (VVR), 2017, № 38-39, st. 380) [Elektronnyj resurs]. - Rezhym dostupu: http://zakonO.rada.gov.ua/laws/show/2145-19 - Дата звернення 02.07.2018.

2. Ukazprezydenta Ukrayiny Pro Nacional»nu stratehiyu rozvytku osvity v Ukrayini na period do 2021 roku. [Elektronnyj resurs]. - Rezhym dostupu: http://zakonO.rada.gov.ua/laws/show/344/2013 - Дата звернення: 12.07.2018.

3. Rozroblennya osvitnix prohram. Metodychni rekomendaciyi / V. M. Zaxarchenko, V. I. Luhovyj, Yu. M. Rashkevych, Zh. V. Talanova / Za red. V. H. Kremenya. - K. : DP «NVC» «Priorytety», 2014. - $120 \mathrm{~s}$. [Elektronnyj resurs]. - Rezhym dostupu: https://shed.org.ua/images/biblioteka/rozroblennya-osv-program2014tempus-office.pdf.- Дата звернення: 15.08.2018.

4. Zahal»noyevropejs»ki Rekomendaciy Izmovnoyi osvity: vyvchennya, vykladannya, ocinyuvannya / Naukovyj redactor ukrayins»koho vydannya doctor ped. nauk, professor S. Yu. Nikolayeva. - K. : Lenvit, 2003. - 
273 s.

5. Stupnykova L. V. Obuchenye professyonal»no oryentyrovannomu dyskursu v pravovoj sfere v uslovyyax mezhkul»turnoho vzaymodejstvyya (anhlyjskyjyazyk, neyazykovojvuz) : dys. kand. ped. nauk / L. V. Stupnykova. M., 2010. - $291 \mathrm{~s}$. $-264 \mathrm{~s}$

6. Karaulov Yu. N. Russkyj yazyk y yazykovaya lychnost» / Yu. N. Karaulov. - M. : Edytoryal URS, 2004.

7. Krois-Linder A. Introduction to International Legal English / A. Krois-Linder, M. Firth. - Cambridge : Cambridge University Press, 2008. - 160 c.

\author{
Наталя Анатоліївна Сорока, \\ доктор філософії з психології, \\ доцент, доцент кафедри іноземних мов № 2 \\ Національного юридичного університету \\ імені Ярослава Мудрого, \\ e-mail: alfa155_sv@ukr.net \\ Маргарита Олексіївна Зайцева, \\ доктор філософії з філології, \\ доцент, доцент кафедри іноземних мов № 2 \\ Національного юридичного університету \\ імені Ярослава Мудрого, \\ e-mail:margozay@i.ua
}

\title{
ПСИХОЛОГО-ПЕДАГОГІЧНІ РЕКОМЕНДАЦЇ̈ ЩОДО НАВЧАННЯ СТУДЕНТІВ ПРЕЗЕНТАЦІЇ ІНШОМОВНОГО ФАХОВОГО МАТЕРІАЛУ
}

Проблема. Одним із найважливіших завдань професійної підготовки майбутніх правників $\epsilon$ необхідність брати участь у різних типах прямих і непрямих міжкультурних комунікацій під час виконання своїх обов'язків.

Метою статті є визначення психолого-педагогічних принщипів для найбільш ефективного навчання студентів стосовно засвоєння ними навичок іноземної мови професійного спрямування за спеціальністю «Міжнародне право» в рамках першого освітньо-кваліфікаційного рівня (бакалавра).

Методи. У статті використані наступні теоретичні методи педагогічного дослідження: вивчення літератури, теоретичний аналіз, методи логічного узагальнення. Разом з теоретичними методами були застосовані й практичні методи: спостереження, розмова та допит.

Основні результати дослідження полягають у визначенні ключових принципів побудови алгоритму навчання ораторського виступу, за умов дотримання яких студенти набувають навички публічного виступу в професійній сфері.

Наукова новизна дослідження полягає в узагальненні існуючих методичних матеріалів щодо розробки презентачій. У статті запропоновано алгоритм, який повинен ураховуватися під час розробки презентації: основна ідея презентаџії, тривалість презентації, структура презентації, інтерактивність презентації, наочність презентації.

Висновки та конкретні пропозиції. У статті надається низка психологічних $і$ методичних рекомендацій з підготовки презентаиій.

Ключові слова: комунікативна компетентність,навички публічного виступу, представлення презентації, професійна комунікачія, інтерактивність презентації, наочність презентації.

\author{
Наталья Анатольевна Сорока, \\ доктор философии по психологии, \\ доцент, доцент кафедры иностранных языков \\ № 2 Национального юридического университета \\ имени Ярослава Мудрого, \\ e-mail: alfa155_sv@ukr.net \\ Маргарита Алексеевна Зайцева, \\ доктор философии по филологии, \\ доцент, доцент кафедры иностранных языков \\ № 2 Национального юридического университета \\ имени Ярослава Мудрого, \\ e-mail: margozay@i.ua
}




\title{
ПСИХОЛОГО-ПЕДАГОГИЧЕСКИЕ РЕКОМЕНДАЦИИ ПО ОБУЧЕНИЮ СТУДЕНТОВ ПРЕЗЕНТАЦИИ ИНОЯЗЫЧНОГО ПРОФЕССИОНАЛЬНОГО МАТЕРИАЛА
}

В статье рассматривается проблема представления презентаций студентами-юристами. Объясняется, что общепринятая иель современного обучения иностранному языку состоит в формировании коммуникативной компетентности, включающей в себя развитие навыков публичного выступления посредством представления презентаций. В статье указан алгоритм, который должны учитьваться при разработке презентации: основная идея презентации, длительность презентации, структура презентации, интерактивность презентации, наглядность презентации. Кроме того, авторь предложсили ряд психологических и методических советов по подготовке презентаций.

Ключевые слова: коммуникативная компетентность, навыки публичного выступления, представление презентации, профессиональная коммуникация, интерактивность презентаџии, наглядность презентации.

\section{Список використаних джерел та літератури}

1. Закон України про Освіту (Відомості Верховної Ради (ВВР), 2017, № 38-39, ст. 380) [Електронний peсурс]. - Режим доступу: http://zakonO.rada.gov.ua/laws/show/2145-19. - Дата звернення: 02.07.2018.

2. Указ президента України про національну стратегію розвитку освіти в Україні на період до 2021 року. [Електронний ресурс]. - Режим доступу: http://zakonO.rada.gov.ua/laws/show/344/2013. - Дата звернення: 12.07.2018.

3. Розроблення освітніх програм. Методичні рекомендації / В. М. Захарченко, В. І. Луговий, Ю. М. Рашкевич, Ж. В. Таланова / за ред. В. Г. Кременя. - К. : ДП «НВЦ «Пріоритети», 2014. - 120 с. [Електронний ресурс]. - Режим доступу: https://shed.org.ua/images/biblioteka/rozroblennya-osv-program2014tempus-office.pdf. - Дата звернення: 15.08.2018.

4. Загальноєвропейські Рекомендації з мовної освіти: вивчення, викладання, оцінювання / Науковий редактор українського видання доктор пед. наук, професор С. Ю. Ніколаєва. - К. : Ленвіт, 2003. - 273 с.

5. Ступникова Л. В. Обучение профессионально ориентированному дискурсу в правовой сфере в условиях межкультурного взаимодействия (английский язык, неязыковой вуз) : дис. канд. пед. наук / Л. В. Ступникова. - М., 2010. - 291 с. $-264 \mathrm{c}$.

6. Караулов Ю. Н. Русский язык и языковая личность / Ю. Н. Караулов. - М. : Едиториал УРС, 2004.

7. Krois-Linder A. Introduction to International Legal English / A. Krois-Linder, M. Firth. - Cambridge : Cambridge University Press, 2008. - 160 c.

Отримано редакцією 21.09.2018 p.

УДК 371.1:372

\author{
DOI: 10.31376/2410-0897-2018-3-38-96-103 \\ Тетяна Олександрівна Пономаренко, \\ доктор педагогічних наук, професор \\ кафедри дошкільної освіти Педагогічного \\ інституту Київського університету \\ імені Бориса Грінченка, \\ e-mail: ponomarenko.tet5@gmail.com
}

\section{ФОРМУВАННЯ ГОТОВНОСТІ МАЙБУТНІХ ФАХІВЦІВ ДОШКІЛЬНОЇ ОСВІТИ ДО ПОЛІКУЛЬТУРНОГО ВИХОВАННЯ ДОШКІЛЬНИКІВ}

У статті розглянуто проблему формування готовності майбутніх фахівиів дошкільної освіти до полікультурного виховання дітей дошкільного віку в умовах педагогічного закладу вищої освіти. Окреслено сутність досліджуваної готовності в єдності ї̈ компонентів (иіннісно-мотиваційного, когнітивнодіяльнісного, особистісного). Визначено актуальність та зміст формування готовності до полікультурного виховання дошкільників, особливості використання технології педагогічного менеджменту в сукупності його етапів: організаційно-мотиваційного, планувального, координаційно-стимулювального, контрольно-оцінювального з метою формування досліджуваної готовності.

Ключові слова: полікультурне виховання, готовність, майбутні фахівиі дошкільної освіти, технологія педагогічного менеджменту, педагогічний заклад вищої освіти.

Постановка проблеми. У сучасних умовах реалізації ефективних довгострокових планів розвитку дошкільної освіти на рівні світових стандартів винятково важливого значення набуває формування якісно нового кадрового педагогічного складу закладів дошкільної освіти. При цьому в контексті сучасних світових і вітчизняних реалій, окрім сукупності традиційних професійних знань, умінь, навичок, загальновизнаних 